\title{
Honey as Medicinal and Food Resource. Comparison between Polish and Multiethnic Settlements of the Atlantic Forest, Misiones, Argentina
}

\author{
Fernando Zamudio ${ }^{1}$, Monika Kujawska ${ }^{2}$ and Norma I. Hilgert ${ }^{*}, 1$ \\ ${ }^{I}$ Centro de Investigaciones del Bosque Atlántico (CeIBA), IBS, UNaM, CONICET, Argentina; ${ }^{2}$ Department of Ethnology \\ and Anthropology of Culture, University of Wroclaw, Poland
}

\begin{abstract}
We present a comparative study on the use of wild honeys produced by insects of the order Hymenoptera in the Criollos (of mixed origin) and Polish populations in the northern part of the province of Misiones, Argentina. The principal questions of the study are: do different types of honey exist that are used for both nutritional and medicinal purposes or on the contrary: do exclusively nutritional and/or medicinal honeys exist? When used medicinally, are these honeys involved in the cure or prevention of similar ailments? The previous report of the use of complex drugs consisting of honey and medicinal plants or other products, led us to inquire about alternative or complementary roles among the sapid and medicinal properties of honeys in these blends. This question is approached from the local understanding of the role of honey in the preparation of medicines, treatments and prevention of common diseases in the area. This study is based partly on the results of two larger projects in progress in the mentioned areas. We prepared an open-ended questionnaire and worked with 16 Polish settlers, and with 23 Criollos farmers. The honeys of two species: bee (Apis mellifera) and yatei (Tetrogonisca angustula) obtained the greatest number of reports within alimentary and medicinal categories of use. They were also employed as functional and medicinal food. In general terms, we found a similar corpus of traditional medical knowledge for both populations. The relation between phytotherapy and zootherapy is evident for Criollos and Polish groups. Nevertheless, they show differences in forms of preparation and administrations. Criollos reported the use of greater number of plant species and more combinations of complex remedies.
\end{abstract}

Keywords: Wild honeys, stingless bees, natural pharmacopeia, functional food, complex medicines, criollos, Ethnobiology.

\section{INTRODUCTION}

From the beginning, Ethnobotanical studies have presented conceptually categorized information from an etic perspective. Therefore, it is common to find analysis of food plants on the one hand, and medicinal ones on the other [1$3]$. These categorizations offered possibility to generate information that could be ordered in a similar way in studies form different regions of the world, and thus helped to make comparisons between them. With the development of quantitative Ethnobotany, the interest for identification of patterns of use and involved processes strengthened the employment of these categorizations from an etic perspective [4].

Etkin and Ross [5] proposed to review these divisions with the objective to organize conceptually medicinal and alimentary uses. They proposed to research links between food and medicine in different cultural groups. Consequently created the concept of functional foods, where a plant is used in superimposed or overlapped medicinal and alimentary contexts. Later Etkin [6] noted the importance of considering other classifications of uses beyond alimentary and medicinal, such as nutritional and pharmaceutical, with the consequent need to develop analysis tools for the overlaps in

*Address correspondence to this author at the Centro de Investigaciones del Bosque Atlántico (CeIBA), IBS, UNaM, CONICET, Argentina; Tel: 00-543757-423356; Fax: 00-54-3757-421984;

E-mail: normahilgert@yahoo.com.ar these two universes. In this context, numerous studies highlighted the potential medicinal benefits of traditional foods, where some of the ingredients have specific pharmacological effects [7-10].

Later, a new division between functional food and medicinal food was added to this discourse by Pieroni and Quave [14]. They described functional food as plants (usually weeds) that are consumed to "be well", without details that allow to establish the exact profit to the health of individuals, thus appearing as "purifying", "to strengthen the blood". While there are various concepts on these foods, there is an agreement that they cover third place, (which overlaps) between food and medicine. Medicinal foods include those resources that are consumed (that is to say, ingested in food contexts) in order to achieve a specific medicinal effect.

American cultures had used honey of various native insects' species of Hymenoptera of New World before the introduction of Apis meliffera to the continent. The prehispanic Maya, who lived at the Yucatan peninsula, Mexico, semi-domesticate one species of stingless bees called xunanKab (Melipona beecheii) [15]. The historical link between honey-producing insects and Guarani, documented by Cadogan, can also be found in Jesuits' writings, who lived with indigenous communities of the Argentine Chaco [16].

Honey is a natural resource with wide medicinal application. In occasions, it is difficult to discern the role assigned to honey in remedies, and therefore, it is complicated to interpret the purpose of its use. In fact, there 
are numerous studies, which registered different values attributed to it. Honeys produced by insects of the order Hymenoptera (bees, wasps and bumblebees) are valued in rural communities for their high energy content, medicinal properties, and diversity of secondary products that can be obtained from them. These insects are represented in different cultural domains of both indigenous and Criollos communities [17- 21]. Nevertheless, these works treat the subject from general perspective and do not provide details of conceptual categorizations of assigned uses. In this work we define wild honey as product of high sugar content, produced by insects of the order Hymenoptera.

Moreover, the factors influencing the consideration of honey as an useful resource and modes of its use is also scarce in literature. Undoubtedly, the wide range of behaviors and life habits of Hymenoptera have led to a large number of local representations that influence the forms of use of products derived from them. According to Cotton [22], decisions regarding the use and management of natural resources are based on a combination of biophysical and socio-cultural factors. These depend on how the individual and the environment are perceived by a person or a whole society. Having in consideration the subject of our study, these decisions are based on culinary preferences, concepts of health and nutritional well being of a given group, and finally, the knowledge and recognition of available resources. Therefore, if the information comes from different cultural groups, it is essential that these influences are taken into account, acknowledged and understood. In this context there are numerous studies analyzing the use of natural resources in multiethnic regions and by immigrants groups [4, 14, 23-27]. They interpret adaptation processes observed in immigrants groups and also in native communities, which get affected by the immigrants' culture.

In the literature on herbal pharmacopoeia can be find different analysis on the number of elements used in a remedy preparation, the mode of administration and the body system for which it is used [11-13]. In the region of our interest, there are available some works dedicated to medicinal plants employed in the phytotherapy of Criollos [28-30], as well as some aspects of knowledge and use of honeys in the indigenous communities $[31,32]$.

In the study region, no previous research has been conducted on neither the role of combinations of animal and plant products with relation to home medicine, functional foods and food medicines; nor a comparison of home medicine among populations of different cultural background.

The objective of this work is to research on the role of wild honeys in the local medicine of rural Criollos and Polish communities from the northern part of Misiones, Argentina. Our interest in particular is to analyze the foodmedicinal use of wild honeys produced by different insect of the order Hymenoptera. The questions that guide the work are: do exist different types of honey for both nutritional and medicinal purposes or on the contrary: do exclusively nutritional and /or medicinal honeys exist? When medicines, are these honeys involved in the cure and /or prevention of similar ailments? The high number of reports of use of complex drugs consisting of honey and medicinal plants or other products, led us to inquire about alternative or complementary role among the sapid and medicinal properties of honeys in these blends. This is approached from the emic perspective, i.e. from the local understanding of the role of honey in the preparation of medicines, treatments and prevention of common diseases in the area. Given the history of arrival and settlements of both study groups in the region, we expect to find differences in medical practices with use and applications of honey and plants. We expect to find in both groups usage that may be categorized as medicinal food.

\section{Studied Area}

The research was conducted in the northern part of Misiones province (Argentina) in two departments: Iguazú and General Manuel Belgrano. Both of them share a border

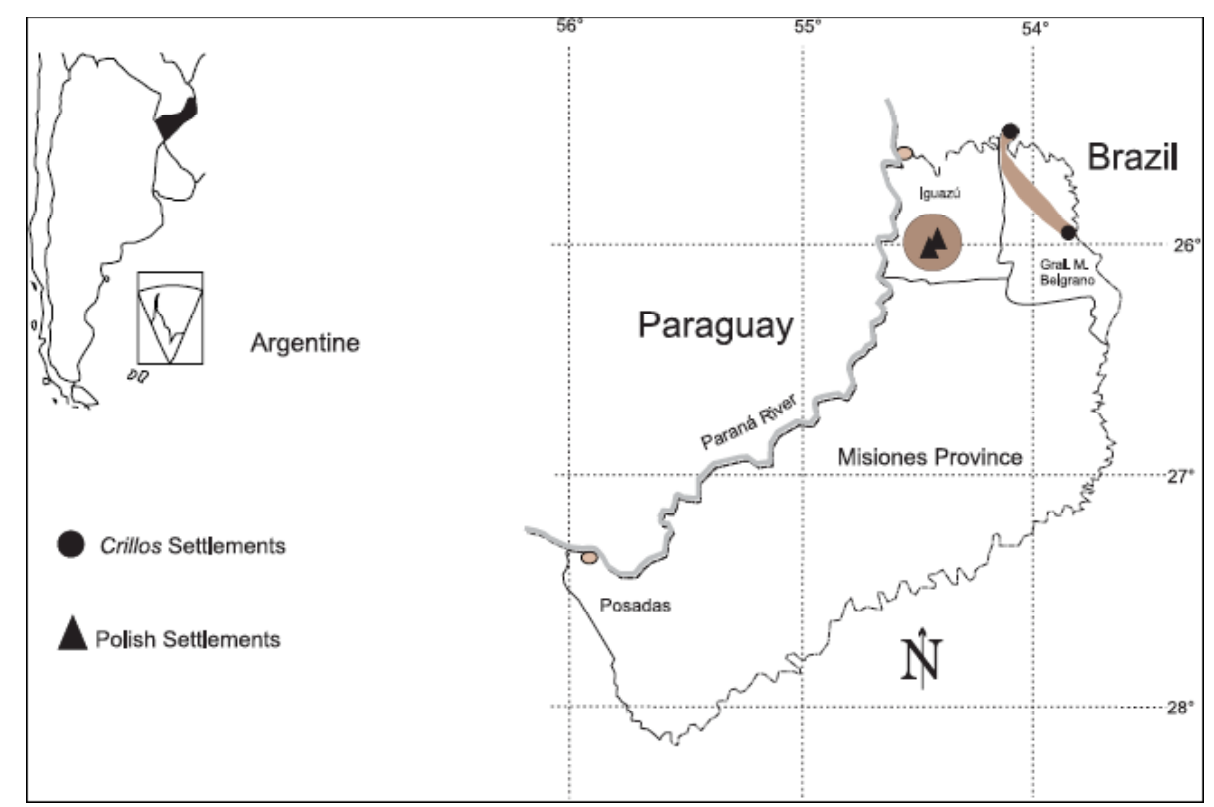

Fig. (1). Criollos and Polish settlements located in the north of the province of Misiones, Argentina. 
with Brazil (in the north and northeast, respectively). The department of Iguazú is also bordered by Paraguay in the west. We worked in two areas: settlements Wanda and Gobernador J.J. Lanusse, department of Iguazú (zone 1), and in hamlets at Andresito Península and Maria Soledad Municipality C, Andresito Guaçurarí and San Antonio (zone 2) (Fig. 1). Despite the relative geographic proximity (60 $\mathrm{km}$ ) of these zones, their inhabitants originate from different cultural backgrounds.

Wanda and Lanusse were established as Polish rural settlements. Wanda, situated on the banks of the Parana River, developed into a town with some semi-rural land on its outskirts. The Lanusse locality, $36 \mathrm{~km}$ from Wanda, never managed to develop administrative, educational and public health infrastructure, therefore many Polish families have left Lanusse and moved to the town of Wanda while continuing to use their land in Lanusse. The studied sites of Peninsula Andresito and Maria Soledad are hamlets with minimal infrastructure (dusty unpaved roads, not completely electrified areas, satellite schools).

The most important economic activities in the region are forestry and agriculture, supplemented by livestock breeding. The first is based on monoculture plantations of pine (Pinus spp.) and eucalyptus (Eucaliptus spp.) for the paper and timber industry based in the area. The main crops are: tobacco (Solanum tabacum), yerba mate (Ilex paraguariensis), tea (Thea sinensis), and fruit plantations, mainly citrus. The provincial economy is based on the raw material extraction with little industrial development [33, 34]. Almost all farmers that were interviewed are small producers.

Both study areas are within the Atlantic Forest Ecoregion [35]. This is a semi-deciduous forest growing in a subtropical climate with hot summers $\left(35-40^{\circ} \mathrm{C}\right)$, between December and March, and winters with frosts between June and August. Average annual rainfall is $1700-2200 \mathrm{~mm}$, with no marked dry season [36].

\section{Poles and Criollos: Definition of Study Groups}

The current population of the province of Misiones is the result of the conjunction and coexistence of the original indigenous population (Mby'a-Guaraní), European and Asiatic immigrants that arrived between 1900 and 1940 and Paraguayan and Brazilian families that fled to the province during the XX century $[33,37,38]$.

The European immigrants, among them Poles, Ukrainians, Swedes, Swiss and Germans, were established in "colonies" of culturally homogeneous formation (Polish colonies, German colonies, etc.). Wanda and Lanusse were founded in 1936 by Colonizadora del Norte, a PolishArgentinean private company that was selling 25 ha lots of land (forest) to Polish peasant families and helped them to settle down in the region. Nowadays Wanda and Lanusse exhibit a multicultural character: in addition to the Polish pioneers and their children, Argentinean migrants from other provinces as well as Paraguayan and Brazilian immigrants live there.

On the other hand, small farmers, living in the hamlets of Península Andresito and María Soledad, are of mixed cultural backgrounds. They obtained their lots through spontaneous occupation that was subsequent to the foundation of overseas immigrant colonies. That occupation was characterized by precarious legal tenure of land, distribution of estates without any pattern and poor infrastructure $[33,34]$. Among the Criollos inhabitants of the study area, there are Argentineans and Brazilians, descendants of Germans who live neighboring to Paraguayan and Argentinean mestizos.

The discernment of Polish and Criollos groups was made in base on three criteria: self-identification, language and customs, and cultural institutions. While most of Polish immigrants and their descendants identify themselves as such, they have maintained their language, tradition and congregated under the cultural institutions (Polish Association of Wanda, Polish Language School, Polish radio program, Polish folk dance group etc.), the Criollos are part of a heterogeneous local culture, characterized by a strong Brazilian cultural influence (alternatively speaking Spanish and Portuguese), are not ascribed to any particular ethnic group and have no institution that would stand out for them as a homogeneous ethnic group. Both Criollos and Polish settlers have little contact with Mby'a Guarani, who live in villages scattered throughout the region.

\section{Background}

In Poland honey has been gathered since many centuries, especially in the forest rich areas. The only bee producing honey is Apis mellifera in this country. First honey was collected from the wild. Nevertheless, this practice was not sustainable and since the Middle Ages was being replaced by breeding bee in hives. The first beehives were located in forests and they were natural holes in old trees. Since the XVIII century natural hives started to disappear. A beekeeper did not have to go to the forest and climb a tree in search for honey anymore. Instead, some pieces of trunk with holes were kept near households. From those primitive hives modern beehives developed in the second part of the XIX century, provided with moving parts, so that honeycombs were not destroyed anymore while collecting honey [39].

Honey was used basically as a remedy, titbit, and as an ingredient for Christmas and wedding cakes by the country inhabitants. In the nobles' houses honey was consumed more frequently in form of fermented alcoholic drink (honey liquor) and in spicy cakes, called pierniki. The honey liquor was a genuine Polish drink, consumed in a large quantity. The consumption of honey liquor decreased in the XIX century due to the popularization of imported wines and vodka. In the country honey beer was sometimes prepared by solvent farmers [39].

In the Polish traditional medicine honey has been a popular remedy to treat respiratory diseases, gastrointestinal disorders and dermatological problems. Honey has also been highly prized as a medicine for heart disorders and for contagious diseases (chickenpox, measles). It has been used pure or in mixture. For example, to treat cold and flu, honey, butter and garlic were added to hot milk and drunk together. Sometimes this home cure was replaced by mixed vodka and honey. To treat contagious diseases, like measles, lactofermented cabbage juice was mixed with whey, honey 
and fat. It was given to children to externalize skin eruption intensively and with this precipitate a healing process. Those cures represent the remedies used mostly in the past [39].

As for the importance of honey in the studied region, the available information can be traced back to the period when Jesuit missionaries arrived to the area, for the indigenous populations of Mby'a [32]. These beneficial insects are central in the cultural representations and mythology of American ethnic groups such as the Maya, Kayapó, Toba, Wichí, Mby'a, among the others. Honey, larvaes, propolis, pollen and wax obtained by these groups are valuable sources of food and medicine [15, 17, 40, 41]. Recent studies with Toba, Wichí and Mby'a indigenous groups revealed their deep understanding of ecological relationships between bees, vegetation and their natural predators [31, 32, 41]. In the province of Misiones, collecting honey from the forest is a traditional activity performed by groups of Mby'a [31, 32, 40] as well as by farmers and new settlers to the area (Europe, Brazil and Paraguay) [42]. However, no information is available for the Criollos communities in this region.

As for the local medicine, some researchers have been carried out in Misiones, especially focusing on herbal medicine of indigenous groups [44], Criollos and new settlers' groups [26, 29, 44-46].

Information on the species of Hymenoptera bees from the region, especially from the tribe Meliponini, is scarce and sometimes refers to studies done in the past and in the neighboring countries [47, 48]. Recently we have found references for the presence of some species of Hymenoptera of Misiones in the Moure's Bees Catalogue [49], while the book of Silveira et al. [50] is a reference to the taxonomy of bees in the region. One problem for the study of use of honeys and bee's ecology is the lack of information on richness, diversity and taxonomy of bee species [51].

\section{MATERIALS AND METHODOLOGY}

This study is based on the results of two larger projects in progress in the mentioned areas. Based on prior local biological knowledge of Hymenoptera, we prepared an openended questionnaire. It consisted of seven sections with questions that sought to understand the contexts of use of Hymenoptera honey that people knew and /or used. Within the alimentary use, we distinguish between the frequent consumption of honey, included in everyday diet and in preparation of festive dishes, and the sporadic one. The latter is defined as an occasional and opportunistic consumption during field activities and trips to the forest, when honey is harvested and eaten at once, without being saved for later on. With regard to the medicinal uses assigned to honey and other products derived from it we wanted to investigate a) the conditions or illnesses treated, b) the forms of preparation and /or administration of remedies that include honey, and c) the role of honey in the preparation of home remedies when they included other elements (plants, animals, pharmaceuticals).

We worked with 16 Polish settlers, aged between 39 and 77 (9 men and 7 women), and with 23 Criollos farmers, aged between 20 and 70 (14 men and 9 women). In both cases the proportion between men and women was similar. They were selected from among adults who formed families. In the Polish population there are both urban and rural inhabitants. For this study only the latter were chosen. Sixteen farmers of Polish origin account for $42 \%$ of all Polish inhabitants in the Lanusse and Wanda region who dedicate themselves to agriculture. We worked with all families that we found present at home at the time of our arrival, except if they were close relatives of one already visited. Criollos participants were chosen randomly from 72 informants.

The information is organized according to topics and informants in Excel tables. With an objective to analyze the number of medicinal uses assigned to honeys, body systems and plant and fat components present in the complex remedies, we used the no parametric Mann-Whitney test (contrast of two independent samples). Contingency tables were made and values compared, by Chi-square test, the richness of medicinal uses of honey, the differences in the application of bee and yatei honeys, and the ways of preparation and administration of medicines, between both populations. In both analyzes Infostat [52] program was used. Finally, the Simpson's similarity index was calculated to find out to what extent Poles and Criollos share the same pool of products, animal and / or plant species, in the preparation of medicines based on honey.

The plants were identified by the authors ( $\mathrm{NH}$ and $\mathrm{MK}$ ) and have been deposited in the herbarium of the Universidad Nacional del Noroeste (UNNE). Some of the bees of the tribe Meliponini were identified by Claus Rasmussen (Department of Entomology, University of Illinois USA) and Fernando Silveira (Department of Zoology, Federal University of Minas Gerais, Brazil), while the rest of the insects were identified by FZ, using taxonomic keys [50, 53]. The insects were deposited in the entomological collection of the Universidad Nacional de Misiones (UNAM). While progress has been made on the correspondence between vernacular and taxonomic species names, some scientific names assigned to ethnospecies could be modified with the advance of the overall project.

\section{RESULTS}

Honey from 17 ethnospecies of Hymenoptera and 2 piqueras (an entrance to a colony made from cerumen - a mixture of wax and plant resins) were named as useful resources. Four different categories of use were registered, as well as restrictions on their consumption (home food and/or sporadic food, medicinal, ornamental and cosmetic). In total, 433 reports were registered; medicinal uses were the most frequently mentioned. Bees (Apoidea) were the most often mentioned insects. The stingless bees of the Meliponini tribe stand out as a useful group (12 ethnospecies).

Taking into account the relative importance assigned to honey (based on the frequency of mentions), Apis mellifera, known locally as bee or eropa - and yatei (Tetragonisca angustula) were the most important. Also the use of honey from two wasps (Vespoidea) and a bumblebee were recorded. The inhabitants of the area group the bees of the tribe Bombina and subtribe Xylocopini under the vernacular name mamangaba (bumblebee), possibly due to morphological and behavioral similarities (Table 1). 
Table 1. Melliferous Hymenoptera Used by Criollos $(\mathrm{N}=\mathbf{2 3})$ and Polish $(\mathrm{N}=16)$ Settlers. Data about the vernacular name, number of total applications, category of use and honey productivity is presented (obtained during interviews). UP= used product: $\mathrm{H}=$ honey; $\mathrm{P}=$ piquera (nest entrance); $\mathrm{HC}=$ household consumption; $\mathrm{SC}=$ sporadic consumption; $\mathrm{MED}=$ medicinal; ORN=ornamental; $C O S=$ cosmetic; $R U=$ restricted uses; *Species cited only by Criollos; $\Theta$ Meliponini Bees

\begin{tabular}{|c|c|c|c|c|c|c|c|c|c|c|}
\hline \multirow{3}{*}{ Vernacular name } & \multirow{3}{*}{ Species } & \multirow{3}{*}{$\begin{array}{l}\text { Total } \\
\text { Uses }\end{array}$} & \multirow{3}{*}{ UP } & \multicolumn{5}{|c|}{ Uses } & \multirow{3}{*}{$\mathbf{R U}$} & \multirow{3}{*}{$\begin{array}{c}\text { Honey production } \\
\text { (Kg) }\end{array}$} \\
\hline & & & & \multicolumn{2}{|c|}{ FOOD } & \multirow{2}{*}{ MED } & \multirow{2}{*}{$\cos$} & \multirow{2}{*}{ ORN } & & \\
\hline & & & & $\mathrm{HC}$ & SC & & & & & \\
\hline Abeja o eropa & Apis mellifera & 185 & $\mathrm{H}$ & 75 & 0 & 105 & 1 & 0 & 4 & $8-25$ \\
\hline Yateí & Tetragonisca angustula $\Theta$ & 125 & $\mathrm{H}$ & 19 & 3 & 100 & 0 & 2 & 1 & $0,3-1$ \\
\hline Carabozá o Irapua o cortapelo & Trigona spinipes $\Theta$ & 19 & $\mathrm{H}$ & 0 & 15 & 7 & 0 & 0 & 1 & $1-3$ \\
\hline Lechiguana & Brachygastra spp & 9 & $\mathrm{H}$ & 1 & 18 & 0 & 0 & 0 & 0 & $0,5-1$ \\
\hline Mambuca & Cephalotrigona $\operatorname{spp} \Theta$ & 9 & $\mathrm{H}$ & 0 & 5 & 0 & 0 & 0 & 0 & $2-4$ \\
\hline Guaraipo & Melipona $\operatorname{spp} \Theta$ & 5 & $\mathrm{H}$ & 1 & 7 & 0 & 0 & 0 & 0 & $1-5$ \\
\hline Iratín * & Lestrimelitta limao $\Theta$ & 5 & $\mathrm{H}, \mathrm{P}$ & 0 & 2 & 1 & 0 & 0 & 0 & $>1$ \\
\hline Caga fogo & Oxytrigona $\operatorname{spp} \Theta$ & 5 & $\mathrm{H}$ & 0 & 1 & 0 & 0 & 0 & 0 & $\mathrm{~s} / \mathrm{d}$ \\
\hline Mandurí & Melipona $\operatorname{spp} \Theta$ & 3 & $\mathrm{H}$ & 0 & 5 & 0 & 0 & 0 & 0 & $1-4$ \\
\hline Carnicera & Agelaia multipicta $\Theta$ & 2 & $\mathrm{H}$ & 0 & 1 & 0 & 0 & 0 & 0 & $>1$ \\
\hline Tachado & Scaptotrigona $\operatorname{spp} \Theta$ & 1 & $\mathrm{H}$ & 0 & 9 & 0 & 0 & 0 & 0 & $1-4$ \\
\hline $\begin{array}{c}\text { Abejas de suelo (guira o } \\
\text { uruzú) }\end{array}$ & Schwarziana $\operatorname{spp} \Theta$ & 1 & $\mathrm{H}$ & 1 & 7 & 0 & 0 & 0 & 0 & $1-3$ \\
\hline
\end{tabular}

According to the perception of local people and their personal experience, the organoleptic characteristics and quantity of honey produced by each ethnospecies is highly variable. For example, honey of carabozá is sometimes considered of bad flavor and not always safe for consumption, for the reason that carabozá feeds on different fluids of dead animals and excrement. Despite the negative associations, carabozá's honey has been relatively frequently used as sporadic food and even medicine. Other honeys, for example mirí and borá's honey, are considered "strong" (mostly the latter) and of sour taste. Some honeys, including honey of the bee (4 citations), are considered harmful when consumed in large quantities.

In all cases the honeys are used as food. Although we registered frequent consumption - particularly of the honey bee and yatei- (Food in Table 1) and a sporadic one, during activities in the field and forest, when a nest is found and honey eaten at once (Sporadic in Table 1). This pattern of use occurs in most reported ethnospecies. It was explained to us that honeys of some species are infrequently used because they are dangerous (e.g. carabozá and caga fuego), for others the scarcity and uneven distribution of nests was the reason of sporadic use (especially of the genus Melipona) and low productivity (e.g. miri), among other factors. However, occasionally we found honeys of some of these ethnospecies in households, stored in jars or bottles. The use of bumblebee and wasp's honeys are rare, given the high risk of being stung during harvesting and usually form a part of adventure games related to childhood and adolescence. However, if a nest is found during field work, performed far from home, it is often exploited in the moment.

The honeys of yatei and bee are the only ones that are consumed both pure and in mixture. Poles consume honey mainly in baked sweets $(40 \%)$ as a sweetener for hot and cold beverages $(30 \%)$ and spread on bread $(24 \%)$. The order of importance changes for the Criollos, who use those mainly pure $(37.8 \%)$, with bread $(18.9 \%)$ for breakfast and tea. Finally these farmers reported on the occasional use of honey with boiled cassava, reviro (traditional dish made from wheat flour, salt and water, fried in fat) and popcorn. Instead, yatei's honey, more liquid, smooth and distinctive in taste, in both studied areas is mainly consumed pure and in lower proportion than bee's honey. As it will be discussed 


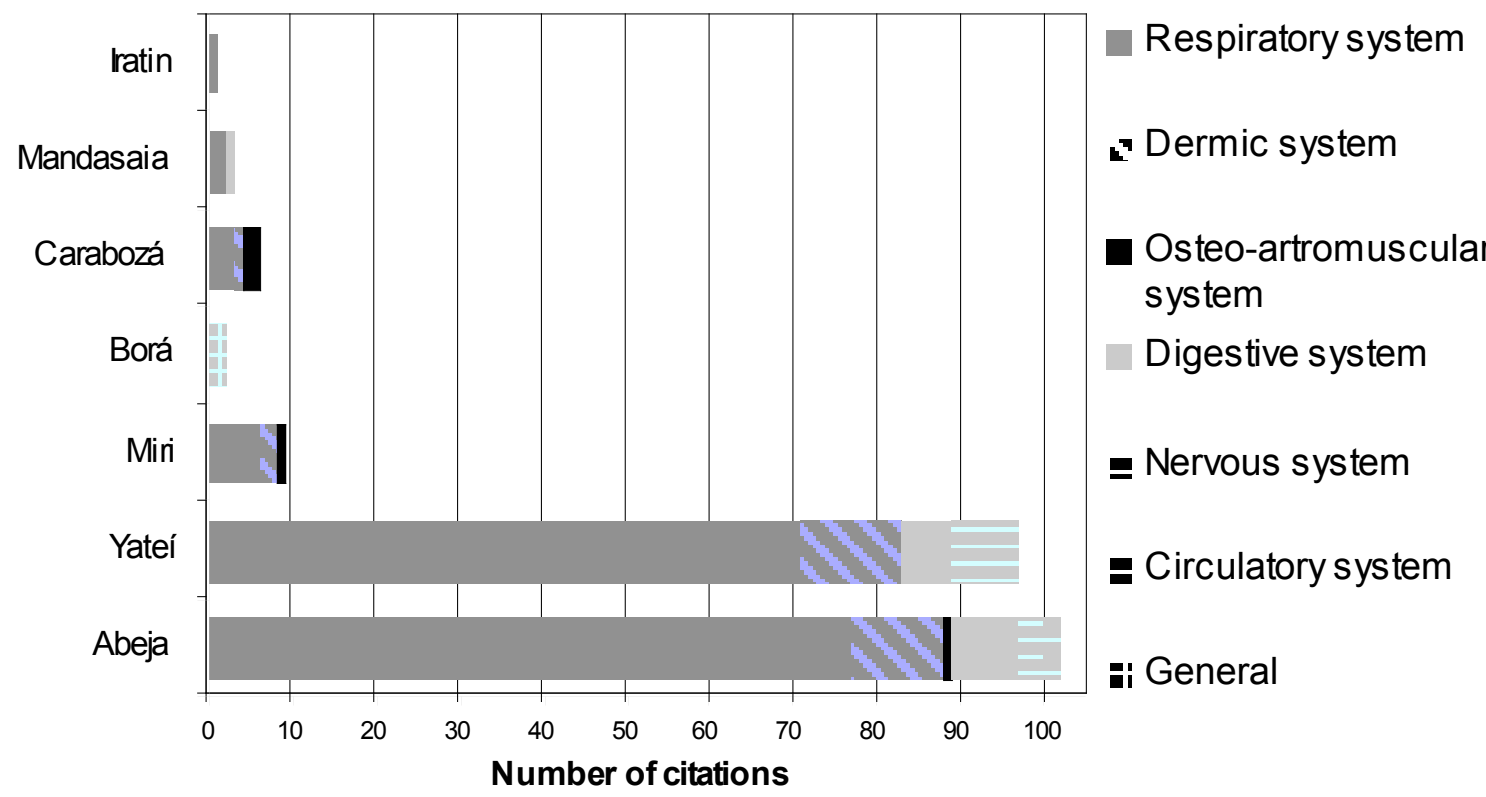

Fig. (2). Total number of mentions (Criollos and Poles) on the medicinal use of honeys from seven different Hymenopteran ethnospecies (listed on the left) used to treat various disorders of body systems (listed on the right) in the north of the Misiones province.

below, although it can be eaten for nutritional purposes, yatei's honey is considered primarily as a medicinal resource.

\section{Medicinal Uses of Honeys}

Seven of the mentioned species were cited for at least one medicinal use. As in the case of food, bee and yatei are the ethnospecies with the largest number of reports (Table 1). The bee's honey was mentioned as a remedy of 6 corporal systems. The yatei had no reports for the circulatory and osteo-artromuscular systems (Fig. 2). The rest of ethnospecies were cited for respiratory system disorders, while the honeys of mirí and carabozá are also used to treat disorders of osteo-artromuscular and dermic systems (Fig. 2). The ethnospecies borá, mandasaia and iratin were exclusively mentioned as medicinal by the Criollo population (Table 1). For the mandasaia and bees, both the use of honey and piquera was reported. Borá, in turn, was cited as medicinal, but no specific reference was made to its use nor to its consumption patterns.

The average number of systems treated with honeys were 2 (SD 1.24) and 1.75 (SD 1.18) in criollos $(\mathrm{N}=36)$ and Polish population $(\mathrm{N}=16)$, respectively. In both cases, the maximum of treated systems per informant was 4 and the minimum 1 . By comparing these independent samples (Mann-Whitney two-tailed test) no significant differences were found: *\# of medicinal uses: $\mathrm{W}=292, \mathrm{P}=0.409$ and $\#$ of corporal systems treated: $\mathrm{W}=300, \mathrm{P}=0.514$.

As the bee and yatei's honeys are distinguished for their richness in medicinal uses, in both populations, so we will analyze these uses in depth. The average number of uses cited per person in the Criollos population was 4.83 (SD 2.53, range 2-11) and 4.5 (SD 3.27, range 2-12) for the Polish population. We found a significantly higher number of citations on the use of honey of yatei among Criollos than among Poles $\left(\chi^{2}=9.33, \mathrm{P}=0.0023, \alpha=0.05\right)$. However, a similar comparison with the bee's honey, did not reveal any significant difference.

\section{Conditions and IIInesses Treated with Honey}

Home remedies based on honey treated most frequently illnesses related to the respiratory system in both populations ( $72 \%$ and $76 \%$, respectively). Between the two populations, honeys from bee and yatei's together were significantly more mentioned by the Criollos for treating the respiratory and skin system $\left(\chi^{2}=6.08, \mathrm{P}=0.014 ; \alpha=0.05\right.$ and $\chi^{2}=7.35, \mathrm{P}=$ $0.006, \alpha=0.05$ ), while the Polish use them more against gastrointestinal disorders $\left(\chi^{2}=5.14, \mathrm{P}=0.023 ; \alpha=0,05\right)$. The differences referring to the respiratory system remain between these two cultures $\left(\chi^{2}=8.80, \mathrm{P}=0.003 ; \alpha=0.05\right)$ when considering only the applications assigned to yatei's honey. Honey of bee, was used significantly more in treatments of the skin system by Criollos $\left(\chi^{2}=4.45, \mathrm{P}=\right.$ $0.035 ; \alpha=0.05)$ and the digestive system by Poles $\left(\chi^{2}=9 ; \mathrm{P}\right.$ $=0.003 ; \alpha=0.05)$.

In total, the surveyed persons cited ten different respiratory ailments that can be treated with bee and yatei's honeys interchangeably. Those cited, as they are called in the area, were: tuberculosis, sore throat, cold, angina, asthma, lung problems, pneumonia, bronchitis, colds, flu and cough. Pulmonary problems and pneumonia were cited only by Criollos. This group also gave a greater number of reports for treatments of bronchitis and flu.

\section{Modes of Preparation and Administration of Home Remedies}

Poles and Criollos prepare home remedies with honey in a similar way but show differences in the frequency of application of a given mode. Among Poles, the most common forms of preparation are the mixture of honey with other components without cooking (cold or heated), followed 


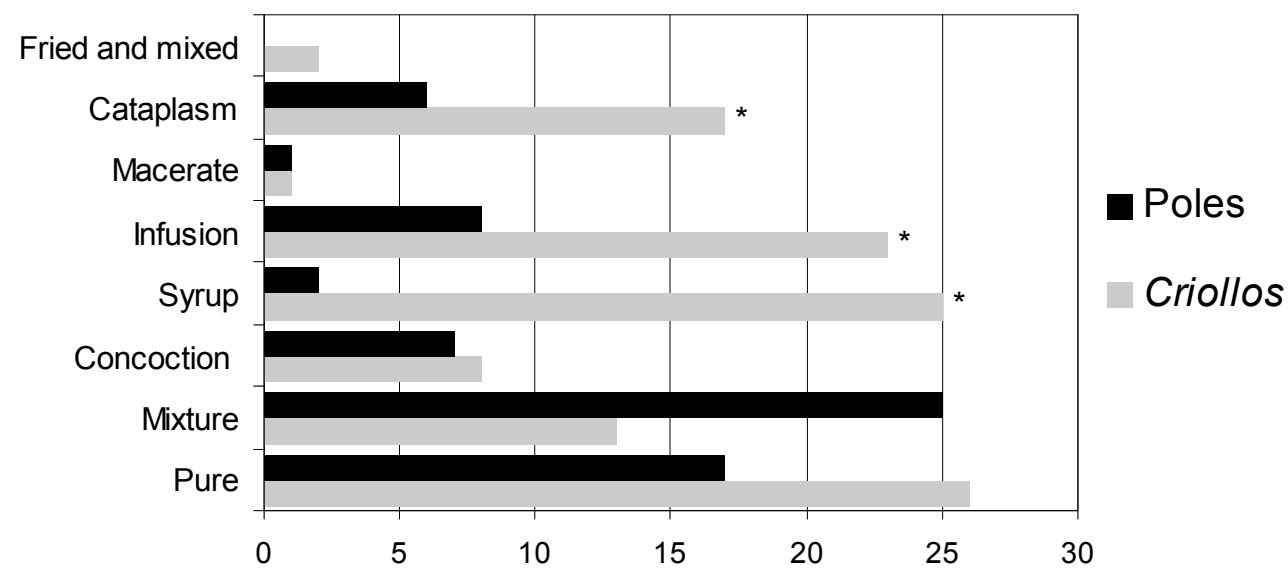

Number of mentions

Fig. (3). Chi square comparison of ways of preparation and administration of honey-based home remedies among Criollos ( $\mathrm{N}=23$ ) and Polish settlers $(\mathrm{N}=16)$, the north of Misiones province. * Indicates significant levels $\mathrm{P}<=0.05$.

by consumption of pure honey and herbal infusions. Among Criollos we found a greater diversity of forms of preparation, cited with similar frequency. The prevailing modes of preparation were: intake of pure honey, followed by infusions, syrups and poultices (Fig. 3).

Syrups or "xarope", are prepared by cooking the honey on the low heat with several leaves or different fruit plants (Table 2), while poultices are made with sheets of paper or leaves of plants dipped in honey and then placed on the affected area (on the chest, on wounds or boils). Another remedy used by Criollos, consists of frying garlic and then mixing it with honey (Fig. 3).

As for ways of preparation and administration in respect to the ethnospecies involved, we found that both groups prefer pure honey of yatei. This is explained by the concept of "purity" and "supreme medical property" associated with this honey, present in both cultures. Poles preferentially use yatei's honey pure and honey of bee in blends with other natural remedies. In contrast, among the Criollos both types of honey are prepared in a similar way, although they use pure honey of yatei more commonly, just as Poles. Poultices are made with both honeys.

\section{Homemade Complex Remedies}

The homemade complex remedies include all cures based on additional components and products used together with honey. These components account for 40 medicinal plant species, obtained in the area, of which 22 are exotic and 18

Table 2. Resources Used in Traditional Home Medicine by Criollos and Poles in the North of Misiones. The Table is Divided into Plant and Animal Resources, Industrially Processed Plant Species, and Pharmaceutical Products, which include a Range of Drugs containing Acetylsalicylic Acid

\begin{tabular}{|c|c|c|c|c|c|c|c|c|c|}
\hline \multirow{2}{*}{$\begin{array}{c}\text { Plant } \\
\text { Vernacular } \\
\text { Name }\end{array}$} & \multirow[b]{2}{*}{ Species } & \multirow[b]{2}{*}{ Family } & \multirow[b]{2}{*}{$\begin{array}{l}\text { Number of } \\
\text { Collections }\end{array}$} & \multirow[b]{2}{*}{$\begin{array}{l}\text { Used } \\
\text { part }\end{array}$} & \multirow[b]{2}{*}{ Origin } & \multicolumn{2}{|c|}{ Criollos } & \multicolumn{2}{|c|}{ Poles } \\
\hline & & & & & & $\begin{array}{c}\text { Number } \\
\text { of } \\
\text { mentions }\end{array}$ & $\%$ & $\begin{array}{c}\text { Number } \\
\text { of } \\
\text { mentions }\end{array}$ & $\%$ \\
\hline Aipo & Foeniculum vulgare Mill. & Apiaceae & FZ109 & Flowers & $\begin{array}{c}\text { Exotic- } \\
\text { adventitious }\end{array}$ & 3 & 2,6 & 0 & 0 \\
\hline Ajo & Allium sativum $\mathrm{L}$. & Alliaceae & & Bulbs & $\begin{array}{l}\text { Exotic- } \\
\text { Cultivated }\end{array}$ & 3 & 2,6 & 0 & 0 \\
\hline Aloe fino & Aloe sp. & Alliaceae & & Leaves & $\begin{array}{c}\text { Exotic- } \\
\text { Cultivated }\end{array}$ & 0 & 0 & 1 & 1,5 \\
\hline Ambay & Cecropia pachystachya Trécul & Cecropiaceae & MK04_07 & $\begin{array}{l}\text { Leaves, } \\
\text { buds }\end{array}$ & Native & 5 & 4,4 & 2 & 3,0 \\
\hline Ananá & Ananas comosus (L.) Merr. & Bromeliaceae & & Fruits & $\begin{array}{c}\text { Exotic- } \\
\text { Cultivated }\end{array}$ & 5 & 4,4 & 0 & 0 \\
\hline Apepú & Citrus aurantium $\mathrm{L}$. & Rutaceae & & $\begin{array}{l}\text { Fruits, } \\
\text { juice }\end{array}$ & $\begin{array}{c}\text { Exotic- } \\
\text { adventitious }\end{array}$ & 1 & 0,9 & 2 & 3,0 \\
\hline Berro & Nasturtium officinale R. Br. & Brassicaceae & & $\begin{array}{c}\text { Leaves } \\
\text { and } \\
\text { stems }\end{array}$ & $\begin{array}{c}\text { Exotic- } \\
\text { adventitious }\end{array}$ & 4 & 3,5 & 0 & 0 \\
\hline
\end{tabular}


(Table 2) Contd.....

\begin{tabular}{|c|c|c|c|c|c|c|c|c|c|}
\hline \multirow{2}{*}{$\begin{array}{c}\text { Plant } \\
\text { Vernacular } \\
\text { Name }\end{array}$} & \multirow[b]{2}{*}{ Species } & \multirow[b]{2}{*}{ Family } & \multirow[b]{2}{*}{$\begin{array}{l}\text { Number of } \\
\text { Collections }\end{array}$} & \multirow[b]{2}{*}{$\begin{array}{l}\text { Used } \\
\text { part }\end{array}$} & \multirow[b]{2}{*}{ Origin } & \multicolumn{2}{|c|}{ Criollos } & \multicolumn{2}{|c|}{ Poles } \\
\hline & & & & & & $\begin{array}{l}\text { Number } \\
\text { of } \\
\text { mentions }\end{array}$ & $\%$ & $\begin{array}{l}\text { Number } \\
\text { of } \\
\text { mentions }\end{array}$ & $\%$ \\
\hline Caraguatá & Bromelia balansae $\mathrm{Mez}$ & Bromeliaceae & & fruits & Native & 1 & 0,9 & 0 & 0 \\
\hline Cebolla & Allium cepa $\mathrm{L}$. & Alliaceae & & bulbs & $\begin{array}{l}\text { Exotic- } \\
\text { Cultivated }\end{array}$ & 1 & 0,9 & 1 & 1,5 \\
\hline Cedrón & $\begin{array}{c}\text { Cymbopogon citratus (DC.) } \\
\text { Stapf }\end{array}$ & Poaceae & FZ106 & Leaves & $\begin{array}{l}\text { Exotic } \\
\text { introduced }\end{array}$ & 3 & 2,6 & 1 & 1,5 \\
\hline Certal en planta & not identified & Asteraceae & MK103_09 & $\begin{array}{l}\text { Leaves } \\
\text { and } \\
\text { stems }\end{array}$ & & $\mathrm{c}$ & 0 & 1 & 1,5 \\
\hline $\begin{array}{l}\text { Citrus in } \\
\text { general }\end{array}$ & Citrus ssp. & Rutaceae & & $\begin{array}{l}\text { fruits, } \\
\text { juice }\end{array}$ & $\begin{array}{l}\text { Exotic- } \\
\text { adventitious }\end{array}$ & 0 & 0 & 2 & $3, \mathrm{E}$ \\
\hline Eucalipto & Eucaliptus ssp. & Myrtaceae & & Leaves & $\begin{array}{c}\text { Exotic- } \\
\text { Cultivated }\end{array}$ & 3 & 2,6 & 3 & 4,5 \\
\hline Floripón & $\begin{array}{c}\text { Brugmansia suaveolens } \\
\text { (Humb. \& Bonpl. ex Willd.) } \\
\text { Bercht. \& J. Presl }\end{array}$ & Solanaceae & MK71_09 & Leaves & $\begin{array}{l}\text { Exotic } \\
\text { introduced }\end{array}$ & 0 & 0 & 1 & 1,5 \\
\hline Gramilla & Cynodon dactylon (L.) Pers. & Poaceae & FZ102 & $\begin{array}{l}\text { Whole } \\
\text { plant }\end{array}$ & $\begin{array}{c}\text { Exotic- } \\
\text { adventitious }\end{array}$ & 1 & 0,9 & 0 & 0 \\
\hline Guabirá & $\begin{array}{c}\text { Campomanesia xanthocarpa } \mathrm{O} \text {. } \\
\text { Berg var. Xanthocarpa }\end{array}$ & Myrtaceae & MK93_09 & Leaves & Native & 1 & 0,9 & 0 & 0 \\
\hline Guaco & $\begin{array}{l}\text { Mikania glomerata Spreng; } \\
\text { and/or M. laevigata Sch. Bip. } \\
\text { ex Baker, M. guaco Bonpl. }\end{array}$ & Asteraceae & & Leaves & $\begin{array}{l}\text { Native- } \\
\text { Cultivated/ } \\
\text { Exotic- } \\
\text { Cultivated }\end{array}$ & 1 & 0,9 & 0 & 0 \\
\hline Lengua de vaca & Chaptalia nutans (L.) Pol. & Asteraceae & MK35_09 & Leaves & Native & 0 & 0 & 1 & 1,5 \\
\hline Lima & $\begin{array}{l}\text { Citrus aurantifolia (Christm.) } \\
\text { Swingle }\end{array}$ & Rutaceae & MK38_09 & Leaves & $\begin{array}{l}\text { Exotic- } \\
\text { Cultivated }\end{array}$ & 2 & 1,8 & 0 & 0 \\
\hline Limón & Citrus limon (L.) Bur. & Rutaceae & & $\begin{array}{l}\text { leaves, } \\
\text { shoot; } \\
\text { fruits, } \\
\text { juice }\end{array}$ & $\begin{array}{l}\text { Exotic- } \\
\text { Cultivated }\end{array}$ & 12 & 18,4 & 9 & 13,6 \\
\hline Lino & Linum usitatissimum Griseb. & Linaceae & & Leaves & $\begin{array}{c}\text { Exotic- } \\
\text { adventitious } \\
\text { and/or } \\
\text { cultivated }\end{array}$ & 1 & 0,9 & 0 & 0 \\
\hline Malva blanca & Sida cordifolia L. & Malvaceae & MK82_09 & Leaves & Native & 1 & 0,9 & 0 & 0 \\
\hline Mamón macho & Carica papaya $\mathrm{L}$. & Caricaceae & & flowers & $\begin{array}{l}\text { Native- } \\
\text { cultived }\end{array}$ & 4 & 3,5 & 0 & 0 \\
\hline Mandarina & Citrus reticulata Blanco & Rutaceae & & Leaves & $\begin{array}{l}\text { Exotic- } \\
\text { Cultivated }\end{array}$ & 2 & 1,8 & 0 & M \\
\hline Manzanilla & Matricaria recutita $\mathrm{L}$. & Asteraceae & MK34_07 & flowers & $\begin{array}{c}\text { Exotic- } \\
\text { adventitious }\end{array}$ & 0 & 0 & 3 & 4,5 \\
\hline Marcela & $\begin{array}{l}\text { Achyrocline satureioides } \\
\text { (Lam.) DC. }\end{array}$ & Asteraceae & & flowers & Native & 0 & 0 & 1 & 1,5 \\
\hline Matico & Baccharis spp. & Asteraceae & MK102_09 & $\begin{array}{l}\text { Leaves } \\
\text { and } \\
\text { stems }\end{array}$ & Native & 0 & 0 & 1 & 1,5 \\
\hline Menta casera & Mentha pulegium L. & Lamiaceae & & Leaves & $\begin{array}{c}\text { Exotic- } \\
\text { adventitious }\end{array}$ & 1 & 0,9 & 0 & 0 \\
\hline Naranja & Citrus sinensis (L.) Osb. & Rutaceae & & $\begin{array}{l}\text { fruits, } \\
\text { epicarp; } \\
\text { leaves }\end{array}$ & $\begin{array}{l}\text { Exotic- } \\
\text { Cultivated }\end{array}$ & 13 & 19,2 & 2 & 3,0 \\
\hline
\end{tabular}




\begin{tabular}{|c|c|c|c|c|c|c|c|c|c|}
\hline \multirow{3}{*}{$\begin{array}{c}\text { Plant } \\
\text { Vernacular } \\
\text { Name }\end{array}$} & \multirow[b]{3}{*}{ Species } & \multirow[b]{3}{*}{ Family } & \multirow[b]{3}{*}{$\begin{array}{l}\text { Number of } \\
\text { Collections }\end{array}$} & \multirow[b]{3}{*}{$\begin{array}{l}\text { Used } \\
\text { part }\end{array}$} & \multirow[b]{3}{*}{ Origin } & \multirow{2}{*}{\multicolumn{2}{|c|}{ Criollos }} & \multirow{2}{*}{\multicolumn{2}{|c|}{ Poles }} \\
\hline & & & & & & & & & \\
\hline & & & & & & $\begin{array}{c}\text { Number } \\
\text { of } \\
\text { mentions }\end{array}$ & $\%$ & $\begin{array}{c}\text { Number } \\
\text { of } \\
\text { mentions }\end{array}$ & $\%$ \\
\hline Oreja de gato & not identified & & & Leaves & & 1 & 0,9 & 0 & 0 \\
\hline Palo amargo & Picrasma crenata (Vell.) Engl. & Simaroubaceae & & Bark & Native & 0 & 0 & 1 & 1,5 \\
\hline Pomelo & Citrus paradisi Macf. & Rutaceae & & $\begin{array}{l}\text { fruits, } \\
\text { juice }\end{array}$ & $\begin{array}{l}\text { Exotic- } \\
\text { Cultivated }\end{array}$ & 2 & 1,8 & 1 & 1,5 \\
\hline Repollo & Brassica oleracea L. & Brassicaceae & & Leaves & $\begin{array}{l}\text { Exotic- } \\
\text { Cultivated }\end{array}$ & 1 & 0,9 & 0 & 0 \\
\hline Sauco & $\begin{array}{l}\text { Sambucus australis Cham. \& } \\
\text { Schltdl. }\end{array}$ & Adoxaceae & MK13_07 & flowers & Native & 3 & 2,6 & 0 & 0 \\
\hline Talera & $\begin{array}{l}\text { Celtis iguanaea (Jacq.) Sarg.; } \\
\text { Celtis brasiliensis (Gardner) } \\
\text { Planch. }\end{array}$ & Ulmaceae & FZ101 & $\begin{array}{l}\text { leaves, } \\
\text { shoots }\end{array}$ & Native & 3 & 2,6 & 0 & 0 \\
\hline Tilo & $\begin{array}{c}\text { Heteropterys glabra Hook. \& } \\
\text { Arn. }\end{array}$ & Malpighiaceae & MK28_09 & $\begin{array}{l}\text { Leaves } \\
\text { and } \\
\text { flowers }\end{array}$ & Native & 0 & 0 & 1 & 1,5 \\
\hline Violeta & not identified & & & Leaves & & 1 & 0,9 & 0 & 0 \\
\hline Pollen & & & & & & 1 & 0,9 & 0 & 0 \\
\hline \multicolumn{10}{|l|}{$\begin{array}{l}\text { Animals } \\
\text { resourse }\end{array}$} \\
\hline Red wine & Vitis vinifera L. subsp. vinifera & Vitaceae & & fruits & & 0 & 0 & 2 & 3,0 \\
\hline Flour & Triticum ssp. & Poaceae & & & & 2 & 1,8 & 0 & 0 \\
\hline Coffee & Coffea arabica $\mathrm{L}$. & Rubiaceae & & seeds & & 0 & 0 & 2 & 3,0 \\
\hline $\begin{array}{l}\text { Sugar cane } \\
\text { spirit }\end{array}$ & Saccharum officinarum L. & Poaceae & & stem & & 1 & 0,9 & 0 & 0 \\
\hline $\begin{array}{l}\text { Oil (maize, } \\
\text { sunflower or } \\
\text { soy) }\end{array}$ & $\begin{array}{l}\text { Zea mays L., Helianthus } \\
\text { annuus L., Glycine max (L.) }\end{array}$ & $\begin{array}{l}\text { Poaceae, } \\
\text { Asteraceae, } \\
\text { Fabaceae }\end{array}$ & & m.p., oil & & 6 & 5,3 & 6 & 9,1 \\
\hline Tea & Thea sinensis $\mathrm{L}$. & Theaceae & & Leaves & & 6 & 5,3 & 9 & $\begin{array}{c}13 \\
6\end{array}$ \\
\hline \multirow[t]{3}{*}{ Pharmaceuticals } & & & & & & 8 & 7,0 & 3 & 4,5 \\
\hline & & & & & Total & 114 & 100 & 66 & $\begin{array}{c}10 \\
0\end{array}$ \\
\hline & & & & \multicolumn{2}{|c|}{ Number of products } & 42 & & 26 & \\
\hline
\end{tabular}

native, 8 plant species that are industrially processed, 3 of animal origin and 1 pharmaceutical drug (Table 2).

Criollos use a greater number of plant species than Poles, and for both groups the exotic prevail over the native ones.
Among the exotic species, 6 species of citrus are included with a high percentage of citations. This is most distinctive among Criollos, who make use of leaves, juice and peel of various citrus species in combination with honey or with other plants and products. Among the industrially processed 
Table 3. General Characteristics of the Composition, Richness and Origin of Products and Species (Animal and Plant) Used in Home Remedies made by Criollos $(\mathrm{N}=23)$ and Poles $(\mathrm{N}=16)$. In total 39 Plant Species were Registered; 36 Identified and 3 Unidentified. The Calculation of the Native and Exotic Taxa was Done, Based on Identified Ones

\begin{tabular}{|c|c|c|c|}
\hline Number of plant species & 28 & 17 & 39 \\
\hline Number of native plant species & 8 & 6 & 16 \\
\hline Number of industrially processed plant species & 4 & 4 & 6 \\
\hline Total number of natural resources & $\begin{array}{c}37 \\
(75,5 \%)\end{array}$ & $\begin{array}{c}25 \\
(48,9 \%)\end{array}$ & 49 \\
\hline Number of exclusive products/species & $\begin{array}{c}25 \\
(51,0 \%)\end{array}$ & $\begin{array}{c}12 \\
(24,5 \%)\end{array}$ & - \\
\hline Number of shared species & $\begin{array}{c}12 \\
(24,5 \%)\end{array}$ & $\begin{array}{c}12 \\
(24,5 \%)\end{array}$ & - \\
\hline
\end{tabular}

plant, the use of black tea and plant oils stands out for both populations. Among the animal products, milk is the most frequently used by Polish immigrants (mixture of milk and honey) and fat of capybara (Hydrochoerus hydrochaeris) is employed in equal proportions (Fig. 4).

When comparing the similarity of components used by both populations, we find a high number of therapeutic resources (plants, animals, industrial products) used exclusively by one group (Table 3) and a low number of shared species and products (12). Simpson's index showed a value of $50 \%$. Similarly, when comparing the composition of the home remedies between the two populations, we found: 1) that Criollos referred to a greater number of plant species, 2) Criollos mentioned a greater number of cures involving plants than Poles $(2,83 \mathrm{P} /$ person 1,63 $\mathrm{P} /$ person, respect- ively), 3) Poles use significantly more home remedies that include fatty components (milk, animal fat and plant oil) (Mann-Whitney $\mathrm{W}=393, \mathrm{P}=0.021$ ), 4) in both populations, preparations that combine honey with other elements can include between 1 to 8 taxa (Criollos) and up to 4 (Poles). The results show that in addition to the differences between groups, there are also differences within each group (Table 4).

\section{The Role of Honey and Other Ingredients in Home Remedies. Contexts of Use.}

Honey is considered "healthy", "pure" and free of preservatives or "chemicals" (the reference to "chemicals", as it is understood in the study area, is related to something unnatural and therefore not healthy, and even potentially

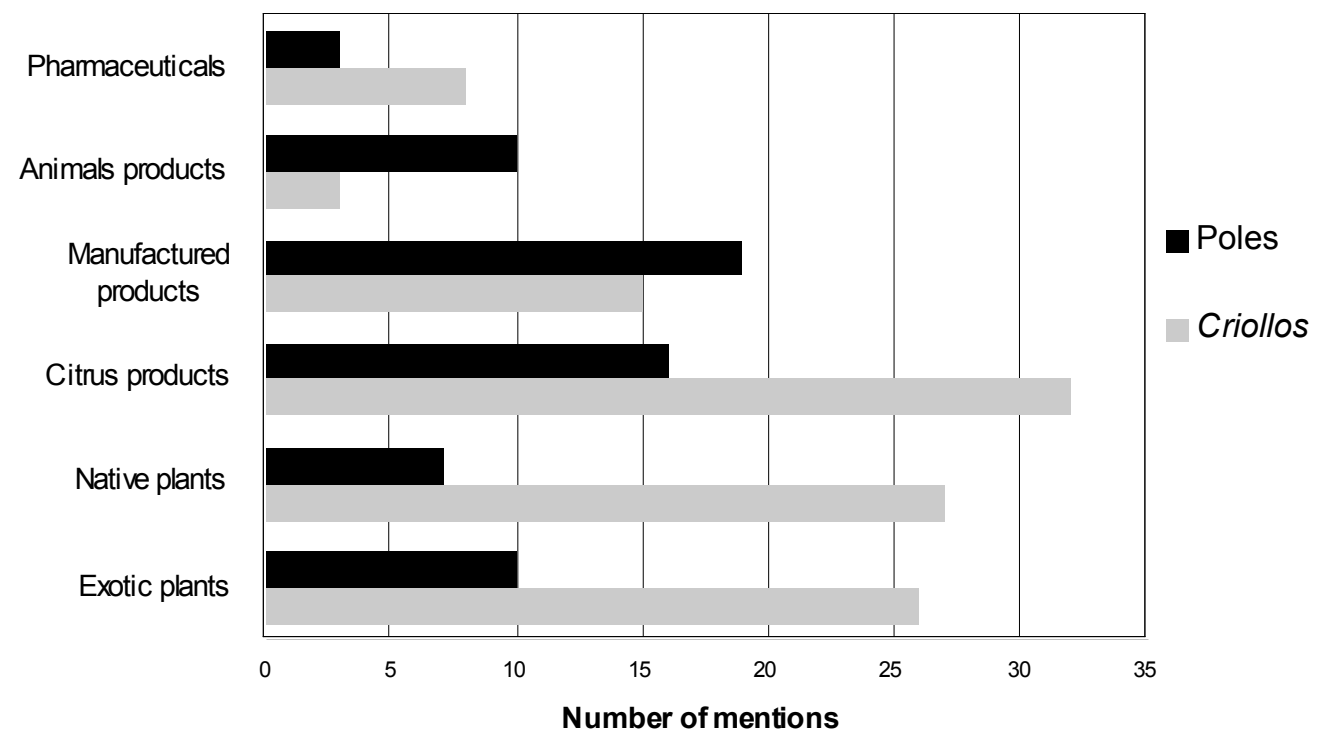

Fig. (4). Number of mentions of the natural products included in honey-based home remedies, according to their origin and forms of preparation for Criollos and Polish populations, the north of Misiones province. Given their high frequency of mentions, the citrus products were marked separately. 
Table 4. Contrast of Two Independent Samples Test (Mann-Whitney) about the Frequency of Reports of Honey-Based Medicines and the Alternative Products/Species Mixed with Honey between Criollos $(\mathrm{N}=23)$ and Polish Settlers $(\mathrm{N}=16)$. Descriptive Statistics and $P$ Value are Present. * Indicates Significant Levels $P<\alpha=0.05$. Nd= Variable Constant

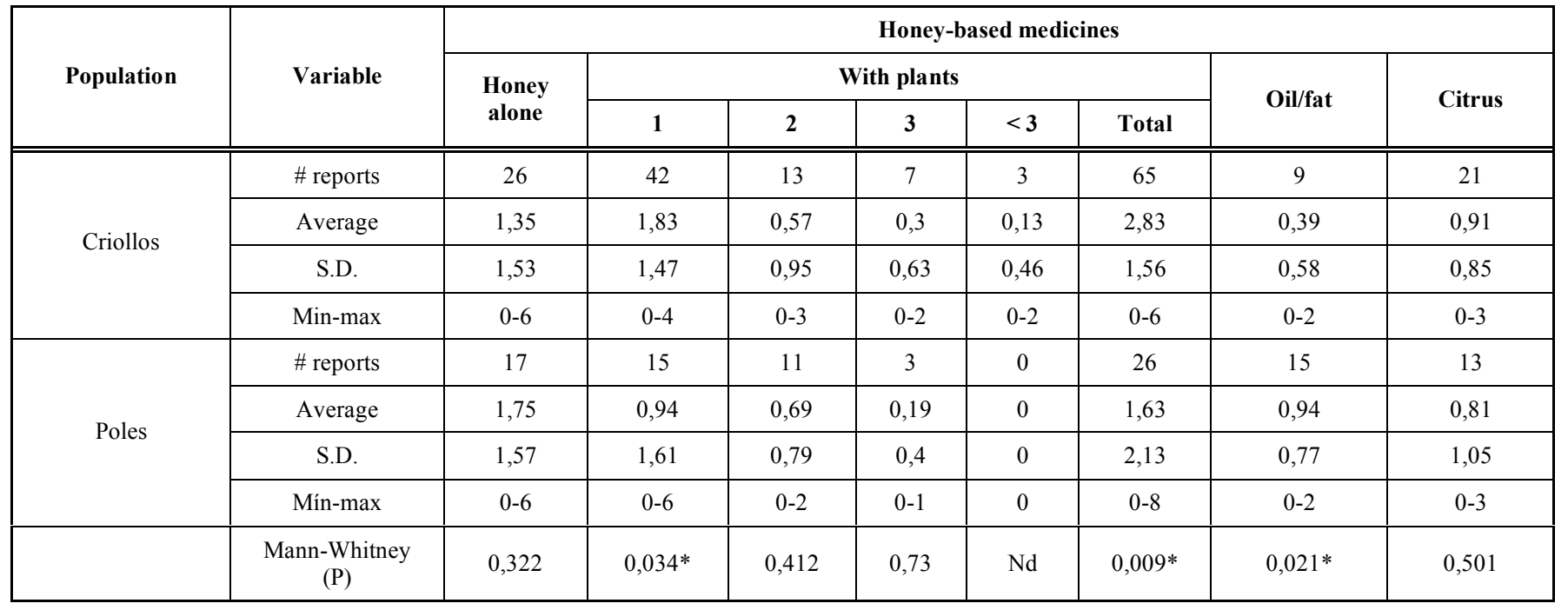

harmful). The role of different ingredients used in the preparation of complex medicines is not always clear to respondents. According to our findings, when combined with other products, honey always possesses a medicinal action (there were a few references on its inclusion as a flavoring). In contrast, in most cases no particular medicinal role was assigned to foods such as milk, black tea, coffee, sugar and vegetable oil. The heated milk mixed with honey has been a part of the traditional Polish pharmacopoeia but now is being replaced by infusions of black tea or citrus leaves by Polish descendants.

The use of milk alone, without the addition of pure honey, has never been mentioned as a remedy by respondents. This finding makes us conclude that the only curative ingredient would be the honey. According to the local explanation, using milk in mixture with honey is 1) a part of tradition, 2) that the hot milk warms the honey; 3 ) to make a remedy more palatable for children. Black tea is used primarily with honey and lemon juice in infusions. In some cases the sudorific property is assigned to it, but mostly it is applied as a flavoring and supplier of liquid to mixture of honey with lemon. Similarly, vegetable oil is added to the honey before warming it. In all these cases, neither oil nor tea or other ingredients mentioned have been used alone as remedies.

Moreover, for some combinations it was explicitly reported that only honey has healing properties and that other components were added to ameliorate symptoms or to promote the curing action, e.g. honey is consumed with vegetable oil and capybara fat to avoid constipation in children and eliminate chest congestion; and poultices are prepared with flour to mature boils, but the flour was only reported as an adherent for a more effective applications of honey.

\section{DISCUSSION}

The stingless bees occupy a prominent place among the species used as food and medicine by Polish settlers and
Criollos, which coincides exactly with the findings of others ethnoentomolgical studies conducted in different regions of America [18, 19, 41, 54- 56]. The high diversity of stingless bee's species (aprox. $300 \mathrm{spp}$. for America) and their behavior [57] would be the reason for the importance of honey among rural inhabitants [57]. In our study this is reflected in the number of used species (12 ethnospecies), in the relative importance (reports), in the number of body systems which are treated with honeys, and in the qualitative evaluations which are attached to these insects ("timid", "dirty", "pretty").

The number of ethnospecies of stingless bees reported in the present work is similar to studies conducted among indigenous groups of Mby'a, living in the same region [31, 32], with 14 y 13 ethnospecies, respectively. Nevertheless, these studies do no present reliable identification of reported species, which hinders a reliable comparison. Similarly, the absence of inventory of Meliponini species for the region, makes it difficult to put into a wider perspective the importance of these taxa in the studied cultures.

In particular, the link between humans and stingless bees was thoroughly documented by Posey [17] among the Kayapó, who recorded the alimentary, materials, medicinal, and ceremonial uses for this group of bees.

Among the Toba and Wichí of the Argentinean Chaco, Arenas [41] reports the use of 9 species of stingless bees (Meliponini). These populations utilize honey, propolis, wax and cerumen to make arrows, and to mend cracks in containers. We also find other, less detailed reports on the use of honey in the same region [58]. The historical importance of honeys of these bees to the Chaco indigenous communities is widely documented by the Jesuit monks, who worked in the region during the XVIII century [16].

In our study yatei and bee received the most reports. The importance attributed to bees is different for different cultural groups. In the literature, it is possible to find species widely cited for many cultural groups and regions such as Trigona spinipies $[17,18,59-61]$. While other less mentioned 
species, are often highly ranked for the cultures that use them.

According to the literature, the importance of honey producing species varies among cultural groups, e.g. Tetragona clavipes and T. trinidadelzsis were identified as the most important insects in the diet of the Yukpa, from the Colombian-Venezuelan border region [62], while the Melipona scutelllaris is a species that received greater relative importance (RI sensu Bennett and Prance [63] in Pernambuco, Brazil) [64]. Occasionally, there can be found reports, in which the European bee receives greater number of medicinal uses than the native species [65], which coincides with findings of our study.

The differences, that we have found, in utilization of honey of bee and yatei, in respect to other species, as we estimate, are due to the cultural and historical reasons. The importance of yatei, can be explained by its importance to the indigenous groups of the region. Indeed, we think that these cultural elements have had more influence than the biological and ecological characteristics of the species, such as honey productivity. In particular yatei is a small insect $(3 \mathrm{~mm})$, with low honey productivity, but gentle and abundant. This species has a central position in the ontogenesis myth of the Guarani culture, where the honey is mentioned as a food that the sun gives to his sister - the moon. In this myth the sun creates the yatei to protect the honey. Consequently, the honey belongs to humankind, in the Guarani's worldview, because the moon is considered one of their ancestors [66]. We presume that the native peoples could have influenced the Criollos populations, and then the immigrants living in the region, on the valuation of this resource. Another factor that could have affected positively and strengthened the medicinal use of yatei's honey today is its promotion in the media and through local markets, as well as its presence in pharmacies, where this honey reaches high prices. While it is difficult to establish the influence of indigenous culture in the current national population, we think that the presence of yatei on the premises, in breeding boxes, and the emotional value it obtains, as an aesthetically pleasing animal, expresses the central role of this insect in the local culture.

On the other hand, bee is a large insect, highly productive, that can be aggressive, and is equally important for both cultural groups. As bee's honey is an important resource in contemporary diet around the world. In the Polish folk culture it has a strong tradition of use [39], and also, in Argentina, bee's honey is among the major agricultural products [67].

The pattern of use, occasional and opportunistic of the edible honeys of most of the reported ethnospecies in this study, makes it difficult to estimate the real importance of this resource in the local diet. In any case, these resources are not available to all members of the family, but mainly to men working in the forest and the agriculture fields, and for children playing in these areas. The context of games in which the honey of wasps was gathered, was documented by Costa-Neto [19]. The importance of honey as a food and nutritional resource has been recorded among various American cultures (Toba and Wichí [41]; Yukpa [62]; Ache [68]; among others). Nevertheless, the current deterioration of natural environments has been a reason for the decline in honey harvesting from the wild by the participants of our study. In fact, the effects of deforestation were measured for stingless bees in subtropical rain forests of America [69-72].

As we observed, only the honeys of bee and yatei are used in the diet of Polish settlers and Criollos with a clearly alimentary purpose. On a daily basis these honeys are consumed for breakfast and tea. The use of honey as an ingredient in baked sweets (honey cakes, honey biscuits) is a part of the Polish cultural heritage. This is reminiscent of the past habits, when Polish farmers led a life based on subsistence farming, so they sweetened everything with honey instead of sugar, to reduce expenses. In different contexts (dessert, snacks, trips to the forest, childhood games, rounds of mate) pure honey was assigned the role of wild sweet, unprocessed and therefore free form chemicals and preservatives, unlike sugar.

\section{Food as Medicine and Medicine as Food}

In both groups, apart from having clearly alimentary and medicinal uses, honey is also applied as functional food [6]. This is explicit as it is considered healthy, pure, and beneficial to the well-being and the health of the human organism. Although it has not been specified, what exact action is produced by honey consumption to preserve health. Honey is consumed by both adults and children, without age discrimination as it is considered totally safe product. It is often consumed pure as titbit, unlike sugar, for its flavor and beneficial action to the organism. Moreover, we presume that honey plays a role of a medicine food, when it is consumed as an energy booster and a preventative of disease (it is considered that the daily consumption raises defenses and avoids respiratory diseases) (coining the terminology proposed by Pieroni \& Quave [14]).

The results indicate that both cultural groups share broadly the same corpus of traditional medical knowledge of yatei and bee species. This was evident in terms of medicinal uses. Honeys of both species were used primarily for respiratory diseases, and within this category, we found a large range of ailments treated with these honeys in both populations. In the literature honeys of bees and wasps are mentioned as remedies for treating a wide variety of diseases, including respiratory ones [18]. However, we have not found studies that would analyze, in particular, ailments and treatments cured with honey. So it is difficult to compare our results with other available works.

The differences observed in the use of honey of yatei can be reflected in greater knowledge and management strategies of local environment by Criollos, who have longer ancestry in the region and stronger links with local groups. By analyzing both cultures separately, there was a higher frequency of use of honey to treat respiratory and digestive systems among Criollos and Poles, respectively. These differences can be understood if we take into account different socio-cultural and environmental contexts, as well as the choice of treatment of diseases in both groups. Criollos, in general terms, are less wealthy and have less access to health centers and pharmacies [73]. Therefore, they rely to a greater extent on home therapy. On the other hand, Poles, turn directly to biomedical specialists, when an illness is recognized as serious (e.g. bronchitis, pneumonia). 
Furthermore, these differences could also be explained by the increased frequency of certain ailments in each group. For example, skin conditions were most commonly reported among Criollos, as they work in predominantly rural and forested areas, what makes them potentially more prone to accidents or attack of insects. Their less favorable health status (due to the economic situation mentioned above) could explain the high incidence of boils. Poles reported significantly greater use of honey for ailments of the gastrointestinal system (mainly for digestive conditions). These conditions can be attributed to the type of their diet high consumption of pork meat. Also the use honey is well established in the Polish folk pharmacopoeia [39]. Although honey is not popular remedy for digestive disorders in Poland, in the new context, immigrants possibly gave greater therapeutic importance to animal products available on the farm (milk, honey, butter and lard) due to the lack of knowledge of the local flora and a great distance to health care centers [74]. This argument is strengthened by the assumption, which states that remedies based on domestic animals are of the European influence [60]. To treat digestive disorders Criollos employ a large pool of plant resources $[45,46]$.

\section{Complex Remedies, Forms of Preparation and Administration}

The use of various natural resources to cure the same illness has been understood as an adaptation to availability /accessibility to them [60].

The results of our research showed little variation in utilization of honeys of different ethnospecies to treat corporal systems. In contrast, the high number of plant species and products used in the preparation of complex medicines are the main strategies used in the area.

The larger number of plant species reported by Criollos (who basically share the use of exotic species with Poles) and the relatively low number of shared plant species in phytotherapy, can be explained by Criollos' more prolonged interaction with the local environment and with descendants of the indigenous groups of the region. While Poles have incorporated native plants in their phytotherapy, this is a recent process. On the other hand, the widespread use of citrus in both groups is possibly an influence of Jesuits' monks in the area [75], and has been strengthened by the availability and accessibility of this resource (always present in home gardens), since it is one of the main crops in the area [34].

Our results revealed a wide range of products of mixed zootherapeutical (in this case honey) and phytotherapeutical components. This link between phytotherapy and zootherapy analyzed in this study was previously demonstrated by Alves \& Rosa [60] and Costa-Neto [18]. Alves \& Rosa [60] describe the therapeutic use of a drink composed of various plants soaked in cachaça (Brazilian sugar cane liquor) or white wine and kept in a bottle with animal's part (Hippocampus reidi and Uca maracoani), called garrafada. In our case a similar concoction (marinated, Table $\mathbf{3}$ ), consisting of equal parts of honey and cachaça along with sabuguero (Aralia soratensis) flowers, was mentioned by one respondent, aged 71, who was born in Rio Grande do
Sul in Brazil but has lived for 40 years in Argentina. Although this may be considered an influence of Brazilian culture, the maceration, on the other hand, has strong roots in the Old World [76, 77]. Other ways of preparations like infusions, poultices and syrups reported in our study, were cited before in the neighboring Argentinean regions [41, 58, 78]. On the other hand, the burning and inhalation of smoke or wax of the nest of some stingless bees practiced among indigenous and rural populations in Brazil [18, 54, 55], is not observed as a form of administration in our study region. The medicinal use of pure honey, especially yatei, is related to the perception of purity and admiration of this insect in the local worldview in Misiones.

In general terms, honey is always attributed with medicinal properties in complex remedies; in contrast, the role of other ingredients in the preparation of complex medicines is not always clear to respondents. As mentioned in the results, we assume that milk; black tea, coffee, sugar and oil play the role of flavoring and conveyance medium in the remedies, and not substances that contribute to the sought pharmacological action.

We think that the richness of natural resources that are combined with honey, compared to other studies that explore the general zootherapy of other populations, is due to several factors: a) the specificity and the depth of the treated subject, b) the heterogeneity of the population with which we worked, c) the richness of medicinal flora in the province of Misiones, d) the importance of herbal pharmacopoeia in Criollos traditional medicine, e) or this was not a specific aim of previous studies. One can find a large and varied number of representations and uses in a local community when the treated topic is limited, even if a studied resource is not of primary importance, as in the study of wasps (Vespoidea), made by Costa-Neto in northeast Brazil. He demonstrated a richness of knowledge and tradition of utility of a group of insects less widely mentioned in ethnoentomology in more general studies [19].

\section{CONCLUSION}

The honeys of two species: bee and yatei held a prominent place among the Hymenoptera species for their alimentary and medicinal applications. They are also employed as functional and medicinal food. In general terms, we found a similar corpus of traditional medical knowledge in both populations. The relation between phytotherapy and zootherapy is evident for both Criollos and Polish groups. Nevertheless, they show differences in forms of preparation and administration. Besides, Criollos use greater number of plant species and make more combinations of complex remedies.

The alimentary and medicinal use of wild honey among the studied communities can be understood by considering: 1) the interactions between the various cultural traditions in the region (original inhabitants, Criollos and national cultures, immigrants' culture), 2) the knowledge of the natural environment, associated with the use and development of daily activities 3 ) the time spent in this type of environment 4) and the socioeconomic status, which in turn translates into access to health care facilities. 
The first supposition, that should be explored in the near future, would explain the presence of exotic species in practices shared by both study groups. The second, greater richness of native species (both Hymenoptera and plants) used by Criollos. In effect, these people are in greater contact with woodlands in good conservational status, and visit them on regular basis to perform various activities (clearing, hunting, harvesting of palm hearts, etc.). Concerning the settlement period in the area, although none are from old settlements, Criollos come from families, which lived in similar environments elsewhere (Brazil, Paraguay and central part of Misiones), whereas Poles come from a temperate climate of central Europe. Finally, relatively high socioeconomic status guarantees health insurance and access to a vehicle, which facilitates access to urban health centers. Indeed, we think that many of the differences found between Poles and Criollos are due to decision making about how and where (in which medical sector) to treat illnesses, having into consideration economic background.

Consequently, Criollos make use of more plant and bee species, and have more ways to combine them. Poles, on the other hand, maintain vestiges of their native pharmacopoeia, enriched and adapted to products and species accessible in the environment. This is a process that should have been more intense at the beginning of their presence in this region.

\section{CONFLICT OF INTEREST}

The authors declare that they have no competing interests.

\section{ACKNOWLEDGEMENTS}

The authors would like to acknowledge to the inhabitants of the settlements under study for their valuable cooperation, patience, and goodwill. We thank the contributions of Guillermo Gil, MS, who made the Figure 1. This study was supported by an independent research grant provided by CONICET (F. Zamudio) and The Rufford Small Grants Foundation. M Kujawska is thankful to Fundación Argentina (Fundacja Argentynska) for the financial support and to Centro de Investigaciones del Bosque Atlántico (CeIBA) for institutional support, space and facilities indispensable for the work on the project. We also thank to H. SaslisLagoudakis an anonymous reviewer for help and comments on the manuscript.

\section{REFERENCES}

[1] Martínez-Crovetto R. La alimentación entre los indios guaraníes de Misiones (República Argentina). Etnobiologica 1968; 4: 1-24.

[2] Martínez-Crovetto R. Introducción a la etnobotánica aborigen del nordeste argentino. Etnobiologica 1968; 11: 1-10.

[3] Murdock GP, Ford CL, Hudson AE, Kennedy R, Simmons LW, Whiting JWM. Guía para la clasificación de los datos culturales. Washington, DC: Unión Panamericana 1960.

[4] Hanazaki N, Peroni N, Begossi A. Edible and healing plants in the ethnobotany of native inhabitants of the amazon and atlantic forest areas of brazil. In: Pieroni A, Price LL, Eds. Eating and Healing. Traditional food as medicine. Binghamton: Haworth Press, 2006; pp. 251-71.

[5] Etkin NL, Roos PJ. Food as medicine and medicine as food: An adaptative framework for the interpretation of plant utilization among the Hausa of northern Nigeria. Soc Sci Med 1982; 16: 155973.

[6] Etkin NL. Eating on the wild side. Tucson: University of Arizona Press. 1994.

[7] Grivertti LE, Ogle BM. Value of traditional foods in meeting macro- and micronutrients needs: The wild plant connection. Nutr Res Rev 2000; 13: 31-46.

[8] Pieroni A. Medicinal plants and food medicines in the folk traditions on the upper Lucca Province, Italy. J Ethnopharmacol 2000; 70: 235-73.

[9] Ogle BM, Tuyet HT, Duyet HN, Dung NNX. Food, feed or medicine: The multiple functions of edible wild plants in Vietnam. Econ Bot 2003; 57: 103-17.

[10] Begossi A, Hanazaki N, Ramos RM. Healthy Fish: Medicinal and Recommended Species in the Amazon and the Atlantic Forest Coast (Brazil) In: Pieroni A, Price LL, Eds. Eating and Healing. Traditional food as medicine. Binghamton: Haworth Press, 2006; pp. 237-71.

[11] Moerman DE. An analysis of the food plants and drug plant of native North America. J Ethnopharmacol 1996; 52: 1-22.

[12] Ososki AL, Lohr P, Reiff M, et al. Ethnobotanical literature survey of medicinal plants in the Dominican Republic used for women's health conditions. J Ethnopharmacol 2002; 79: 285-98.

[13] Hilgert NI, Gil GE. Plants of the Las Yungas Biosphere Reserve, Northwest of Argentina, used in health care. Biodivers Conserv 2006; 15: 2565-94.

[14] Pieroni A, Quave CL. Functional Foods or Food Medicines? On the consumption of wild plants among albanians and southern italians in lucania. In: Pieroni A, Price LL, Eds. Eating and Healing. Traditional food as medicine. Binghamton: Haworth Press, 2006; pp. 101-30.

[15] Cortopassi ML, Emperatriz-Fonseca VL, Roubik DW, et al. Global meliponiculture: challenges and opportunities. Apidologie 2006; 37: 275-92.

[16] Medrano MC, Rosso CN. De la Utilización de Mieles Nativas por Guaycurúes; una aproximación etnobiológica. Biologica 2009; 10: 38-42.

[17] Posey DA. Folk Apiculture of the Kayapo Indians of Brazil. Biotropica 1983; 15: 154-8.

[18] Costa-Neto EM. The use of insects in folk medicine in the state of bahia, northeastern brazil, with notes on insects reported elsewhere in brazilian folk medicine. Hum Ecol 2002; 30: 245-63.

[19] Costa-Neto. EM. Implications and applications of folk Zootherapy in the state of Bahia, Northeastern Brazil. Sustain Dev 2004; 12: 161-74.

[20] Alves RR, Rosa IL. Zootherapeutic practices among fishing communities in North and Northeast Brazil: A comparison. J Ethnopharmacol 2007; 111: 82-103.

[21] Mahawar MM, Jaroli DP. Traditional knowledge on zootherapeutic uses by the Saharia tribe of Rajasthan. Indian $\mathrm{J}$ Ethnobiol Ethnomed 2007; 25: 1-6.

[22] Cotton CM. Ethnobotany. Principles and applications. Chichester: John Wiley \& Sons 1996.

[23] Albuquerque UP. The use of medicinal plants by the cultural descendants of African people in Brazil. Acta Farm Bonaerense 2001; 20: 139-44.

[24] Pieroni A, Muenz H, Akbulut M, Baser KHC, Durmuskahya C. Traditional phytotherapy and trans-cultural pharmacy among Turkish migrants living in Cologne, Germany. J Ethnopharmacol 2005; 102: 69-88.

[25] Kujawska M. Plants used in Polish immigrants 'phytotherapy Misiones, Argentina. Introduction to the problem. In: Mirek Z, Flakus A, Krzanowski A, Eds. The nature and culture of latin america. review of polish studies. Krakow: W. Szafer Institute of Botany, Polish Academy of Science 2009 (in press).

[26] Begossi A, Hanazaki N, Tamashiro JY. Medicinal plants in the Atlantic Forest (Brazil): Knowledge, use and conservation. Hum Ecol 2002; 30: 281-99.

[27] Atran S, Medin D, Ross N, et al. Folkecology, cultural epidemiology, and the spirit of the commons. Curr Anthropol 2002; 43: 421-50

[28] Sawchuk B. Descripción de árboles medicinales de la selva misionera. Ministerio de Asuntos Agrarios - Estación experimental agropecuaria Cerro Azul: 1983. 
[29] Amat AG, Yajía ME. Plantas vasculares utilizadas en la fitoterapia popular de la Provincia de Misiones, Argentina. In: Amat A. Ed. Farmacobotánica y farmacognosia en Argentina (1980 - 1998). La Plata, Argentina: Ediciones Científicas Americanas1998: pp. 11952.

[30] Amat AG, Yajia ME. Plantas Medicinales y Etnofarmacología en la Provincia de Misiones (Argentina). Acta Farm Bonaerense 1991; 10: $153-9$.

[31] Cebolla Badie MV. La miel en la cultura mbya-guaraní. Tesis doctoral. Barcelona: Universidad de Barcelona 2004.

[32] Do Santos Rodrigues A. Etnoconhecimento sobre abellas sem ferrão: saberes e práticas dos índios Guarani m’bya na mata atlántica. Tesis Piracicaba Estado de São Paulo- Brasil 2005.

[33] Schiavoni G. Organización doméstica y apropiación de tierras fiscales en la Provincia de Misiones (Argentina). Desarrollo Econ 1995; 34: 595-608.

[34] Schiavoni G. Colonos y ocupantes: parentesco, reciprocidad y diferenciación social en la frontera agraria de Misiones. Posadas, Argentina: Editorial Universitaria Universidad Nacional de Misiones 1998.

[35] Dinerstein E, Olson D, Graham D, et al. Conservation Assessment of the Terrestrial Ecoregions of Latin America and the Caribbean. Washington, DC: The World Bank 1995.

[36] Crespo JA. Ecología de la comunidad de mamíferos del Parque Nacional Iguazú, Misiones. Rev MACN Ecol 1982; 3: 45-162.

[37] Bonasewicz A. La emigración polaca a América Latina. In: Opatrny J Ed. Emigración centroeuropea a América Latina. Universidad Carolina de Praga: Karolinum, 2000; pp. 51-5

[38] Belastegui HM. Los colonos de Misiones. 1st ed. Posadas: Editorial universitaria, Universidad Nacional de Misiones 2004.

[39] Szelagowska E, Nowosad J, Pszczoła S. Rzecz o pszczelarzeniu, Torun: Muzeum Etnograficzne 2006.

[40] Cadogan L. Arandu pova va'e Jakaira gui (Los que reciben buena ciencia de los Jakaira). Boletín de la Sociedad Científica del Paraguay 1957; vol 1.

[41] Arenas P. Etnografía y Alimentación entre los Tobañachilamole\#ek y wichí-lhuku'tas del chaco central (Argentina). Buenos Aires: el autor 2003.

[42] Nogueira-Neto P. Vida y criação de abelhas indígenas sem ferrão. São Paulo. Brasil: Nogueirapis 1997.

[43] Cadogan L. Síntesis de la medicina racional y mística mby'aguaraní. América Indígena 1949; 9: 21-35.

[44] Martinez-Crovetto R. Plantas reguladoras de la fecundidad utilizadas en la medicina popular del nordeste argentino. Am Indíg 1987; 47: 279-93.

[45] Keller HA, Romero HF. Plantas medicinales utilizadas por campesinos del área de influencia de la Reserva de Biósfera Yabotí (Misiones, Argentina). Bonplandia 2006; 15: 1-16.

[46] Moreau D. El uso de las plantas medicinales en la provincia de Misiones (Argentina) y su valorización como recurso en la atención primaria de la salud: exploración de una alternativa de conservación del bosque atlántico del Alto Paraná. Estudio de caso en una población campesina de Comandante Andresito. Misiones Argentina: Fundación Vida Silvestre Argentina 2009.

[47] Bertoni AW. Contribución á la biología de las avispas y abejas del Paraguay (Hymenoptera). An Museo Nac Buenos Aires 1911; 22: 97-146.

[48] Holmberg EL. Viaje a Misiones. Bol Acad Nac Ciencias Córdoba 1887; 10: 252-88.

[49] Moure JS, Urban D, Melo GAR. Catalogue of Bees (Hymenoptera, Apoidea) in the Neotropical Region [monograph on the internet]. Paraná Brazil: Universidad Federal do Paraná; 2008. [cited 2009 Nov 10]. Available from: http://www.moure.cria.org.br/catalogue

[50] Silveira FA, Melo GAR, Almeida EAB. Abelhas Brasileiras, Sistemática e Identificação. Belo Horizonte, Brazil; Edição dos autores 2002 .

[51] Freitas BM, Imperatriz-Fonseca VL, Medina LM, et al. Diversity, threats and conservation of native bees in the Neotropics. Apidologie 2009; 40: 332-46.

[52] Di Rienzo JA, Casanoves F, Balzarini MG, Gonzalez L, Tablada M, Robledo CW. InfoStat. Grupo InfoStat, FCA, Universidad Nacional de Córdoba: Version 2009.
[53] Hermes MG, Köhler A. The genus Agelaia Lepeletier (Hymenoptera, Vespidae, Polistinae) in Rio Grande do Sul, Brazil. Rev Bras Entomol 2004; 48: 135-8.

[54] Costa-Neto EM. Healing with animals in Feira de Santana City, Bahia, Brazil. J Ethnopharmacol 1999; 65: 225-30.

[55] Costa-Neto EM. Recursos animais utilizados na medicina tradicional dos indios Pankarares, que habitam no Nordeste do estado da Bahía, Brasil. Actual Biol 1999; 21: 69-79.

[56] Costa-Neto EM, Ramos-Elorduy J, Pino JM. Los insectos medicinales de Brasil: primeros resultados. Bol Soc Entomol Aragon 2006; 38: 395-414.

[57] Roubik DW. Ecology and natural history of tropical bees. Cambridge UK: Cambridge University Press 1989.

[58] Martinez G. Farmacopea natural en la etnomedicina de los tobas del Río Bermejito (Chaco, Argentina). Tesis doctoral. FCA Universidad Nacional de Córdoba, Argentina 2008.

[59] Costa-Neto EM, Oliveira MVM. Cockroach is good for asthma: zootherapeutic practices in Northeastern Brazil. Hum Ecol Rev 2000; 7: 41-51.

[60] Alves RR, Rosa IL. From cnidarians to mammals: The use of animals as remedies in fishing communities in NE Brazil. J Ethnopharmacol 2006; 107: 259-76.

[61] Alves RR, Rosa IL, Santana GG. The role of animal-derived remedies as complementary medicine in Brazil. Bioscience 2007; 57: 949-55.

[62] Ruddle K. The Human Use of Insects: Examples from the Yukpa. Biotropica 1973; 5: 94-101.

[63] Bennett BC, Prance GT. Introduced plants in the indigenous pharmacopeia of northern South America. Econ Bot 2000; 54: 90 102 .

[64] Almeida CFC, Albuquerque UP. Uso e conservação de plantas e animais medicinais no estado de Pernambuco: um estudo de caso no Agreste. Interciencia 2002; 27: 276-85.

[65] Ferreira FS, Brito SV, Ribeiro SC, Almeida WO, Alves RRN Zootherapeutics utilized by residents of the community Poço Dantas, Crato-CE, Brazil. J Ethnobiol Ethnomed 2009; 21(Pt 5): 110 .

[66] Bartolomé MA. Chamanismo y Religión entre los ava-katu-ete. Biblioteca Parag Antropol 1991; 11: 1-176.

[67] CEDIT. Características y cría de las yateí y otras meliponas. Posadas, Misiones: Comité Ejecutivo de Desarrollo e Innovación Tecnológica 2005.

[68] Hill K, Hawkes K, Hurtado M, Kaplan H. Seasonal Variance in the Diet of Ache Hunter-Gatherers in Eastern Paraguay. Hum Ecol 1984; 12: 101-35.

[69] Kerr WE, Carvalho GA, Nascimento VA. The probable consequences of the destruction of Brazilian stingless bees. In: Padoch C, Marcio Ayres J, Pinedo-Vasquez MA, Andrew A. Eds. Vareza: Diversity, Development and Conservation of Amazonia's Water Floodplains. NewYork: New York Botanical Garden Press 1999: 395-403.

[70] Brown JC, Albrecht C. The effect of tropical deforestation on stingless bees of the genus Melipona (Insecta: Hymenoptera: Apide: Meliponini) in central Rondonia, Brazil. J Biogeogr 2001; 28: 623-34

[71] Samejima H, Marzuki M, Nagamitsu T, Nakasizuka T. The effects of human disturbance on a stingless bee community in a tropical rainforest. Biol Conserv 2004; 120: 577-87.

[72] Cairns CE, Villanueva-Gutierrez R, Koptur R, Bray DB. Bee Populations, Forest Disturbance, and Africanization in México. Biotropica 2005; 37: 686-92.

[73] Gorosito Kramer, AM. Encontros e desencontros. Relações interétnicas e representações em Misiones (Argentina). Dissertação de Mestrado Programa de Pós-Graduacao em Antropología, Universidade de Brasilia 1982.

[74] Kujawska M. Nie czas chorowac, czas pracowac. Stosunek do leczenia sis polskich osadnikow z prowincji Misiones(Argentyna). In: Penkala-Gawecka D. Ed. Conferential proceedings. Antropologia medyczna w Polsce - doswiadczenia, pola badan, perspektywy, Poznan, Uniwersytet im. Adama Mickiewicza Collegium Historicum 2009 (in press).

[75] Ambroseti JB. Viajes a misiones por Juan Bautista Ambrosetti. Buenos Aires: Albatros 2008. 
[76] Pardo de Santayana M, San Miguel E, Morales R. Digestive Beverages As a Medicinal Food in a Cattle-Farming Community in Northern Spain (Campoo, Cantabria). In: Pieroni A, Price LL, Eds. Eating and Healing. Traditional food as medicine. Binghamton: Haworth Press, 2006: 131-151.
[77] Ríos Ruiz S, Martínez Francés V. Plantas de los herberos en la Sierra Mariola (SW de Valencia, N-NW de Alicante, España). Flora Montiberica 2003, 25: 42-51.

[78] Scarpa GF. Medicinal Plants Used by the Criollos of Northwestern Argentine Chaco. J Ethnopharmacol 2004; 91: 115-135.

Received: January 05,2010

Revised: February 08, 2010

Accepted: February 10, 2010

(C) Zamudio et al.; Licensee Bentham Open.

This is an open access article licensed under the terms of the Creative Commons Attribution Non-Commercial License (http://creativecommons.org/licenses/by$\mathrm{nc} / 3.0 /$ ), which permits unrestricted, non-commercial use, distribution and reproduction in any medium, provided the work is properly cited. 